\title{
Efficacy of topical clobetasol propionate in the treatment of idiopathic granulomatous mastitis
}

\author{
İdiyopatik granülomatöz mastit tedavisinde yerel klobetazol propionatın etkinliği
}

\author{
Züleyha YAZICI ÖZGEN, Elif CÖMERT, Mustafa Ümit UĞURLU
}

\begin{abstract}
Objectives: To evaluate the efficacy of topical clobetasol propionate $0.05 \%$ pomade in the treatment of idiopathic granulomatous mastitis.

Patients and Methods: Twenty-one idiopathic granulomatous mastitis patients' clinical and histopathological findings were retrospectively reviewed. Those patients excluded from other etiologies were categorized as idiopathic granulomatous mastitis and treated with topical clobetasol propionate $0.05 \%$ pomade as an initial treatment.

Results: All 21 patients with a final diagnosis of idiopathic granulomatous mastitis were women with the average age of $36.2+/-5.2$ years. Of the 21 patients; erythema, induration and pain problems of $6(28.5 \%)$ patients totally resolved without recurrence in 3 months follow-up period. Erythema, induration and pain problems of $7(33.5 \%)$ patients were minimalized and stay stable in 3 months follow-up period. The symptoms of 8 (38\%) did not change under topical clobetasol propionate treatment. None of the patients developed side or adverse effects due to topical steroid treatment and 6 of 18 patients with non-steroidal anti-inflammatory drugs (NSAIDs) complained of gastric pain.

Conclusion:Topical steroid treatment is a safe treatment option for idiopathic granulomatous mastitis patients before systemic steroid and immunosuppressive treatments and also surgery.
\end{abstract}

Keywords: Idiopathic granulomatous mastitis, Granulomatous mastitis, Mastitis, Topical Steroid, Steroid

Züleyha Yazıcı Özgen (凶), Elif Cömert

Department of Dermatology, School of Medicine, Marmara University, Pendik, Istanbul, Turkey

e-mail: yazicizuleyha@gmail.com

Mustafa Ümit Uğurlu

Department of General Surgery, School of Medicine, Marmara University, Pendik, Istanbul, Turkey

Submitted / Gönderilme: 27.07.2018

Accepted/Kabul: 08.09.2018
ÖZ

Amaç: İdiyopatik granulomatöz mastit tedavisinde topikal klobetazol propiyonat $\% 0,05$ pomadın etkinliğini değerlendirmek.

Hastalar ve Yöntemler: Klinik ve histopatolojik olarak idiyopatik granülomatöz mastit tanıs1 konulan 21 hastanın dosyası retrospektif olarak incelendi. Altta yatan başka patoloji saptanmayan hastalar idiyopatik granülomatöz mastit olarak sinıflandirıld 1 ve ilk tedavi olarak topikal klobetazol propiyonat $\%$ 0,05 pomad uyguland.

Bulgular: İdiyopatik granülomatöz mastit tanılı 21 kadın hastanın yaş ortalaması 36,2 $\pm 5,2$ yıldı. Yirmi bir hastanın $6(\%$ $28,5)$ 'sının eritem, sertlik ve ağrı problemleri tamamen geriledi ve 3 aylık takip döneminde tekrarlamadı. Hastaların 7 (\% 33,5)'sinde eritem, sertlik ve ağrı şikayetleri tama yakın geriledi ve 3 ay süreli takiplerinde artış izlenmedi. Sekiz (\%38) hastada iyileşme gözlenmedi. Hastalarda yerel steroid tedavisine bağlı yan etki görülmezken, ek olarak non-steroid antiinflamatuvar (NSAI) ilaç kullanan 18 hastanın 6'sında mide ağrısı şikayetleri gelişti.

Sonuç: Yerel steroid tedavileri idiyopatik granülomatöz mastit tedavisinde etkili ve güvenli tedavi seçenekleridir.

Anahtar kelimeler: İdiyopatik granülomatöz mastit, Granülomatöz mastit, Mastit, Yerel steroid, Steroid

\section{Introduction}

Idiopathic granulomatous mastitis (IGM) is a benign inflammatory condition of the breast with unknown etiology. Several mechanisms have been proposed, including autoimmune process, infectious diseases and hormonal distruption [1]. The localized autoimmune inflammatory response to retained milk secretions in the duct has been postulated in the pathogenesis of IGM [2-4]. IGM occurs most commonly in parous young women, it may be seen also in nulliparous women and rarely men $[5,6]$. There is no increased risk of subsequent breast cancer in patients with IGM [7]. The breast mass, abscesses, erythema, induration and tenderness are the common clinical findings 
of IGM. The nipple retraction, sinus formation, fistula and axillar adenopathy may accompany these findings. The malignancies, bacterial mastitis, tuberculosis, sarcoidosis, deep fungal infections, foreign body granulomas and autoimmune diseases should be considered in the differential diagnosis of IGM $[1,2,4]$. The challenging diagnosis of IGM requires exclusion of all other possible disorders with a multidisciplinary approach. There are studies reporting about association between IGM and Corynebacterium kroppenstedtii infection and elevated prolactin levels $[8,9]$.

The treatment options are controversial. The reports of spontaneous remissions lead observation or conservative treatments such as symptomatic treatments, systemic antibotics, steroids and immunsuppressive drugs [10]. In some reports; for recurrent cases excision of the affected tissue have been proposed as a treatment option [10].

\section{Material and Methods}

We conducted a retrospective study to evaluate the efficacy of topical clobetasol propionate $0.05 \%$ pomade in the treatment of IGM. The files of 21 IGM patients treated with topical clobetasol propionate at least for 2 months in the general surgery and the dermatology outpatient clinics from April 2014 to July 2017 were analyzed. The patients were included in this study if they had histopathologic confirmation of granulomatous mastitis and excluded the other possible disorders by breast ultrasonograpy, polymerase chain reaction (PCR) for Mycobacterium tuberculosis, chest radiography, bacterial and fungal tissue cultures. Those in whom no underlying etiology was found were categorized as having IGM and treated with topical clobetasol propionate with or without oral non-steroidal anti-inflammatory drug (NSAID) at least 2 months.

All statistical analyses were performed with the Statistical Package for Social Sciences (SPSS) Statistics 20.0 software. The descriptive data were analyzed according to the frequency, percentage, average and standard deviation. Chi-Square and Mann - Whitney U tests were used to compare qualitative data.

\section{Results}

The files of 21 patients with IGM those applied topical clobetasol propionate $0.05 \%$ pomade twice a day, at least for 2 months were analyzed retrospectively. Eighteen of 21 patients were also treated with oral steroidal antiinflammatory drugs (NSAIDs). The most common presenting symptoms and signs were unilateral erythema, infiltration, massand mastalgia in the patients. All patients had the histologic findings consistent with granulomatous mastitis without caseous necrosis. All had normal chest radiography. The breast cancer was assessed in all patients with ultrasonographic imaging.

No identifiable etiology was found in any of the patients who were diagnosed with IGM. All patients were women with an average age of $36.2+/-5.2$ years. None of them has personal or family history for the breast cancer or tuberculosis. Six of 21 ( $28.5 \%$ ) were cigarette smokers. Six of $21(28.5 \%)$ used oral contraseptives at any time in the last 3 years. All women had nursed their children with double breast at least 4 months. Three (14.3\%) women presented during breastfeeding. None of 21 patients were pregnant at the time of presentation. There were abscess drainage histories in 4 of $21(19 \%)$ patients. None of the patients except 1 had systemic symptoms. One patient suffered coexisting erythema nodosum and artralgia. All patients had erythema, infiltration and tenderness on affected breast's skin. All patients except 1 had unilateral findings. Nine patients had abscess and fistula formation. The patient characteristics are summarized in Table I.

Table I. Characteristics of patients with idiopathic granulomatous mastitis $(n=21)$

\begin{tabular}{|l|l|l|l|l|}
\hline & Min & Max & Average & $\begin{array}{l}\text { Standard } \\
\text { Deviation }\end{array}$ \\
\hline Age & 26 & 47 & 36.2 & 5.2 \\
\hline Duration of disease (month) & 3 & 36 & 11.22 & 9.05 \\
\hline Number of pregnancy & 1 & 4 & 2.76 & 1.38 \\
\hline Time from last pregnancy (month) & 14 & 180 & 75.00 & 36.29 \\
\hline Total breasfeeding duration (month) & 4 & 72 & 24.73 & 12.37 \\
\hline
\end{tabular}

All histopathological examinations were established with ultrasound-guided tru-cut biopsy. The initial treatment with topical clobetasol propionate $0.05 \%$ pomade was given to all patients for at least 2 months. Of the 21 patients; 6 patients' $(28.5 \%)$ erythema, induration and pain totally resolved within 2 months of treatment without recurrence after 3 months off-therapy period. Seven patients' (33.5\%) erythema, induration and pain resolved with minimal erythema and induration and did not worsen for 3 months follow-up period. Eight patients' (38\%) symptoms did not improve with topical clobetasol propionate treatment. Total $62 \%$ of patients had complete or partial remission off-therapy. None of the patients developed side or adverse 
effects due to topical steroid treatment. Six of 18 patients treated with NSAID had complaints of gastric pain.

\section{Discussion}

Idiopathic granulomatous mastitis (IGM) is a chronic inflammatory disorder of the breast tissue without proven etiology $[1,2,4]$. Although, patients do not have systemic findings, in some reports erythema nodosum and arthritis were associated with IGM [11]. IGM is generally seen in young-or middle-aged women unilaterally after giving birth. Autoimmune reactions against milk which leak from breast lobules is the suspected mechanism of the disease. The patients generally present with breast mass that should be differentiated from breast cancer by imaging and histopathological examination.

The IGM shows non-caseating granulomatous inflammation in the lobules on histopathological examination. After exclusion of malignancies, etiology for granulomatous mastitis as Mycobacterium infections, foreign body granulomas, fungal infections, Corynebacterium infection, sarcoidosis, Sjögren's disease, vasculitis and other autoimmune diseases should be evaluated. Clear screening for differential diagnoses leads for the diagnosis of IGM. The combination of clinical history, histopatology, laboratory and imaging findings with multidisciplinary approach is critical in the diagnosis and treatment of the IGM.

There is no consensus on treatment however, step by step treatment by antibiotics, steroids and then immunosuppressives and finally excision is suggested in the literature. The prognosis of the IGM is variable.

The successful results with systemic corticosteroid therapy was first reported in 1980 [12]. There are 1 case report and 1 prospective and 1 retrospective study by the same group in the literature on IGM treatment with topical steroid therapy [13-15]. The latest report analyzed topical prednisolone $0.125 \%$ pomade from 28 patients with biopsy-proven IGM, retrospectively. After initial complete remission, during 4 months follow-up period, only $10.7 \%$ of the patients had disease recurrence in whom a repeated course of topical prednisolone treatment resulted with complete healing in most patients. According to results of this study, topical steroid treatment seemed to be very effective in the treatment of IGM [15].

A meta-analysis in 2017 reviewed the complete remission (CR) and recurrence rates of various reported treatments for IGM [10]. According to this study; a pooled estimate of complete remission and recurrence rates for surgical managements were $90.6 \%$ and $6.8 \%$, oral steroids were $71.8 \%$ and $20.9 \%$, oral steroids+surgical managements were $94.5 \%$ and $4 \%$, oral steroids +methotrexate were $71.4 \%$ and unknown, observation were $95.1 \%$ and $9.2 \%$ and finally of topical steroids were $98.8 \%$ and $14.3 \%$, respectively. All the studies about topical steroid efficacy in the treatment of IGM which also analyzed in this meta-analysis were mentioned above [14,15]. This meta-analysis assessed 4 reports of observation in IGM [16-19]. The number of patients were between 3 and 8 in the 3 of these 4 reports $[16,18,19]$. There were 27 patients,with $100 \% \mathrm{CR}$ rate and $11.1 \%$ recurrence rate during average 7.4 months follow-up period, in the report of Bouton et al. [17].

The success rate of observation without treatment, topical steroids and advanced treatment options were reported similar and high in the literature. Despite the fact that strength of topical clobetasol propionate is superior than topical prednisolone, the remission rates are inferior relatively in our study. This might be due to lower number of patients, shorter medication period, resistance of our cases or the prolonged activity of various antibiotics those used in previous study. Our study has a $62 \%$ total complete and partial remission rate and it is still an effective response result for IGM.

There is still no consensus on how to manage this benign condition properly. This is mostly due to its rarity and lack of well-designed studies. Previous studies and our study showed that topical steroid treatment is a safe alternative for the modalities with more adverse event risks such as systemic steroid, immunsuppressive agents and surgery . In the light of recent studies surgical treatments and medical treatments with possible side effects might be reserved for those in whom conservative modalities such as observation and topical steroids are not effective or who ask to have a rapid amelioration.

The limitations of our study are retrospective design of the study, the lack of longer follow-up period and the lack of an observational arm results. Our study and previous studies show the necessity of the randomised, placebo controlled studies and that it is worth observing and/or trying topical steroids in the treatment of IGM before advanced options in the selected cases. 


\section{Conclusion}

Our study suggests to treat IGM with topical steroids before the options with more adverse event risks and also less cosmetic results as systemic steroids, immunosupressive agents and surgery.

\section{References}

1. Baslaim MM, Khayat HA, Al-Amoudi SA. Idiopathic granulomatous mastitis: a heterogenous disease with variable clinical presentations. World J Surg 2007; 31:1677-81. doi: 10.1007/s00268-007-9116-1

2. Ocal K, Dag A, Turkmenoglu O, et al. Granulomatous mastitis: Clinical, pathological features and management. Breast J 2010; 16: 176-82. doi: 10.1111/j.1524-4741.2009.00879.x

3. Yılmaz TU, Gürel B, Güler SA, et al. Scoring idiopathic granulomatous mastitis: an effective system for predicting recurrence? Eur J Breast Health 2018; 14:112-16. doi: 10.5152/ejbh.2018.3709

4. Benson JR, Dumitru D. Idiopathic granulomatous mastitis: presentation, investigation and management. Future Oncol 2016;12: 1381-94. doi: 10.2217/fon-2015-0038

5. Al-khaaf B, Knox F, Bundred NJ. Idiopathic granulomatous mastitis: a 25-year experince. J Am Coll Surg 2008; 206: 269-73. doi: 10.1016/j.jamcollsurg.2007.07.041

6. Azlina AF, Ariza Z, Arni T, et al. Chronic granulomatous mastitis: diagnostic and therapeutic considerations. World J Surg 2003; 27: 515 - 18. doi: 10.1007/s00268-003-6806-1

7. Moris D, Damaskos C, Davakis S, et al. Is idiopathic granulomatous mastitis a surgical disease? The jury is still out. Ann Transl Med 2017;5:309-13. doi: 10.21037/ atm.2017.05.24

8. Kieffer P, Dukic R, Huiber M, et al. A young woman with granulomatous mastitis: a corynebacteria may be involved in the pathogenesis of this disease. Rev Med Intern 2006; 27 : 550-4. doi: 10.1016/j.revmed.2006.03.033
9. Cserni G, Szajki K. Granulomatous lobuler mastitis following drug-induced galactorrhea and blunt trauma. Breast J 1999;5:398-403.

10. Lei X, Chen K, Zhu L, et al. Treatment for idiopathic granulomatous mastitis: systematic review and metaanalysis. Breastfeed Med 2017; 12:415-21. doi: 10.1089/ bfm.2017.0030

11. Gumus M, Akkurt ZM, Gumus H. Is erythema nodosum coexisting with lesions of the breast a suggestive sign for idiopathic granulomatous mastitis? Turk J Surg 2018; 34:713. doi: 10.5152/turkjsurg.2017.3161

12. DeHertogh DA, Rossof AH, Harris AA. et al. Prednisone management of granulomatous mastitis. N Engl J Med 1980; 303:799-800. doi: 10.1056/NEJM198010023031406

13. Altıntoprak F. Topical steroids to treat granulomatous mastitis: A case report. Korean J Intern Med 2011; 26:356-9. doi: 10.3904/kjim.2011.26.3.356

14. Gunduz Y, Antıntoprak F, Ayhan LT, et al. Effect of topical steroid treatment on Idiopathic Granulomatous Mastitis: clinical and radiological evaluation. The Breast J 2014;20:586-91. doi: 10.1111/tbj.12335

15. Altıntoprak F, Kıvilcım, Yalkın O, et al. Topical steroids are effective in the treatment of Idiopathic Granulomatous mastitis. World J Surg 2015;39: 2718-23. doi: 10.1007/ s00268-015-3147-9

16. Pandey TS, Mackinnon JC, Bressler L, et al. Idiopathic granulomatous mastitis-a prospective study of 49 woman and treatment outcomes with steroid therapy. Breast J 2014; 20:258-66. doi: 10.1111/tbj.12263

17. Bouton ME, Jayaram L, O'Neill PJ, et al. Management of idiopathic granulomatous mastitis with observation. Am J Surg 2015; 210: 258-62. doi:10.1016/j.amjsurg.2014.08.044

18. Mahlab-Guri K, Asher I, Allweis T, et al. Granulomatous lobular mastitis. Isr Med Assoc J 2015; 17:476-80.

19. Hur SM, Cho DH, Lee SK, et al. Experience of treatment of patients with granulomatous lobular mastitis. J Korean Surg Soc 2013;85:1-6. doi: 10.4174/jkss.2013.85.1.1 